\title{
Ethnomedicinal plants and practices related to pregnancy, childbirth, and postpartum healthcare of Minangkabau ethnic group, West Sumatra, Indonesia
}

\author{
MARINA SILALAHI ${ }^{1, \boldsymbol{v}}$, ARDIAN KHAIRIAH ${ }^{2}$, NISYAWATI ${ }^{3}$ \\ ${ }^{1}$ Department of Biology Education, Faculty of Education and Teacher Training, Universitas Kristen Indonesia, Jakarta. Jl. Mayjen Sutoyo No. 2, \\ Cawang, Jakarta Timur13630, Jakarta, Indonesia. Tel. +62-21-8009190, 8092425. Fax. +62-21-80886882, `email: marina_biouki@yahoo.com; \\ marina.silalahi@uki.ac.id \\ ${ }^{2}$ Department of Biology, Faculty of Science and Technology, Universitas Islam Negeri Syarif Hidayatullah Jakarta. Jl. Ir. H. Djuanda No. 95, Ciputat, \\ Tangerang Selatan 15412, Banten, Indonesia \\ ${ }^{3}$ Department of Biology, Faculty of Mathematics and Natural Sciences, Universitas Indonesia. J1. Lingkar UI, E Building UI Campus, Depok 16242, \\ West Java, Indonesia
}

Manuscript received: 10 June 2020. Revision accepted: 11 September 2020.

\begin{abstract}
Silalahi M, Khairiah A, Nisyawati. 2020. Ethnomedicinal plants and practices related to pregnancy, childbirth, and postpartum healthcare of Minangkabau ethnic group, West Sumatra, Indonesia. Biodiversitas 21: 4597-4605. In the Minangkabau ethnic cultures, medicinal plants have been used to treat health problems associated with pregnancy, childbirth, and postpartum period (PCP). The objectives of this study were to (i) document the medicinal plants used during pregnancy, childbirth, and postpartum recovery by Minangkabau ethnics and the associated ethnomedicinal practices, and (ii) identify plants that have the potential to be developed as ingredients to increase the production of breast milk. Data were collected in three villages, namely Guguak Sarai, Taruang Taruang, and Sungai Durian in West Sumatra, Indonesia, by interviewing a total of 141 informants, involving 9 key informants and 132 general respondents. A total of 42 species of medicinal plants were found to be used for PCP healthcare by Minangkabau people. These medicinal plants are used to facilitate childbirth, alleviate menstruation problems, assist recovery after miscarriage, mitigate postpartum hemorrhage, aid in postpartum recovery, and for infant care. A total of 26 species were represented by 9 families i.e. Poaceae (7 species), Arecaceae, Fabaceae, Zingiberaceae (3 species respectively), Euphorbiaceae, Lamiaceae, Meliaceae, Musaceae, and Asteraceae ( 2 species each). Majority of the used medicinal preparations are administered by drinking ( 35 species), bathing (4 species), and as a paste ( 3 species). Use of Musa balbisiana, Carallia brachiata, Lansium domesticum, and Toona sureni for treating problems related to pregnancy, childbirth, and postpartum period need to be further investigated for their phytochemistry and pharmacological properties. Plectranthus ambonicus and Sauropus androgynus are used to increase breast milk production, and further research is needed for standardizing processing and commercialization of these species.
\end{abstract}

Keywords: Minangkabau ethnic, PCP, Plectranthus ambonicus, Sauropus androgynus

\section{INTRODUCTION}

Pregnancy, childbirth, and postpartum (PCP) are resulting in considerable deaths, especially in developing countries. The factors that contributed to the death are postnatal bleeding (Tsu et al. 2004), postpartum hemorrhage, and postpartum depression (Abdillahi and Van Staden 2013). The local communities in Asia such as Laos (de Boer and Lamxay 2009; de Boer et al. 2011), Indonesia (Silalahi and Nisyawati 2019), Malaysia (Teoh et al. 2013), Thailand (Panyaphu et al. 2011), India (Jain et al. 2011) use medicinal plants to reduce the death risk of the PCP mothers. About 52.9\% of studied mothers ingested herbs during the post-partum period in Malaysia (Theo et al. 2013).

Various ethnic groups in Indonesia use plants for PCP management, based on local knowledge and make them integral part of the PCP process such as oukup (Silalahi and Nisyawati 2019). The purposes of the use of medicinal plants during PCP are: to restore stamina and to increase breast milk (Silalahi and Nisyawati 2019); to heal the wounds, reduce postpartum hemorrhage, reduce pain during childbirth, and to protect baby from infection (Silalahi and Nisyawati 2019); to improve the health of babies, to facilitate labor and delivery (Theo et al. 2013), and to alleviate menstruation problems (De Boer and Lamxay 2009). The process of acculturation, use of synthetic drugs, and weakening of oral knowledge inheritance systems resulted in the degradation of local knowledge, even though it is an important source of information on biodiversity and cultural conservation (Suryadarma 2010; Emmanuel and Didier 2012; Sujarwo and Cuneva 2016). Knowledge of the use of medicinal plants is derived from experience or inheritance from close family for generations (Emmanuel and Didier 2012).

The problems that postpartum mothers face are maternity blues, depression (Takashi et al. 2014), and stress. Stress has directly or indirectly affected production of breast milk so that some mothers fail to provide good nutrition to the baby. The traditional health system develops various therapies to improve PCP of the mother's health through diet and herbs (Jain et al. 2011; Theo et al. 
2013) and steam bathing (Silalahi and Nisyawati 2019) Silalahi and Nisyawati (2019) stated that various plants used in saunas by postpartum mothers have a relaxing effect so that they can reduce postpartum stress.

The plants used to maintain health varies between one ethnic group and another, which is influenced by various factors such as the biodiversity of the surrounding environment, topography, and culture (Silalahi et al. 2015; Sujarwo and Cuneva 2016). This resulted in the species and number of medicinal plants being recognized differences among ethnic groups. Fifty-four medicinal plant species were used to overcome 15 types of maternal postpartum disorders in the Laos local community (Lundh 2007), while the Batak ethnic group used 63 species as adequate ingredients (Silalahi and Nisyawati 2019) and 88 species for oke show ceremony by Halmahera communities (Wahkidah et al. 2017).

Research on medicinal plants conducted so far in Sumatra mostly focused on documenting their uses in general. Studies on plants curing PCP are severely limited (Silalahi and Nisyawati 2019), especially in the Minangkabau ethnic group. This study aims (i) to reveal local knowledge of Minangkabau ethnicity in utilizing medicinal plants to improve health during pregnancy, childbirth, and postpartum, and (ii) to compare the cultural values or CSI values of the plants used.

\section{MATERIALS AND METHODS}

The study was conducted in three villages (nagari), namely the Guguak Sarai, Taruang Taruang, and Sungai Durian of IX Koto Sungai Lasi Sub-district, Solok District, West Sumatra, Indonesia (Figure 1). These nagari's represent the locations of Minangkabau ethnic groups in the West Sumatra. The study was conducted from February to June 2016. The Minangkabau ethnic connecting the area is called "Minangkabau land" which means unity between territory, social system, and culture contained within them and has a system of matrilineal kinship. Empirically, the Minangkabau ethnic groups are known to be rich in local knowledge of using herbs and spices, and research has proved that they are rich in traditional medicine (Kairiah 2017). The Minangkabau is an ethnic group that adheres to the matrilineal kinship. The child in the matrilineal system has a bond with the mother's brother called mamak (uncle).

\section{Data collection}

Data were collected from a total of 141 informants, consisting of 9 key informants and 132 general respondents, ranging in age from 30 to 80 years (Table 1). More than $95 \%$ of the people living are Minangkabau and the rest are Javanese. More than $90 \%$ of them are farmers, the rests are traders and government employees. Respondents were selected with purposive snowball sampling methods. Information on diversity of medicinal plants used as medicinal plants was obtained from the respondents with semi-structured, in-depth interviews, and participative observation methods. Interviews were conducted according to the existing methods (Martin,1995), with some modifications.

Medicinal plants are collected as voucher specimens and their local names, parts used, life forms, uses, and process of preparation are recorded. The identification of voucher specimens was carried out at Laing's Spice and Drug Plant Research Institute, Solok, specifically in Plant Taxonomy Laboratory, Faculty of Mathematics and Natural Sciences, Universitas Indonesia, Depok, and Herbarium Bogoriense, Institute of Sciences (LIPI), Cibinong, Indonesia. The voucher specimens were stored at Laing's Spice and Drug Plant Research Institute, Solok, West Sumatra, Indonesia. The scientific names are verified with the Plantlist Database (www.theplantlist.org.)

Table 1. The demographic information of respondents of the Minangkabau ethnic group, West Sumatra, Indonesia

\begin{tabular}{llll}
\hline Characteristics & $\begin{array}{c}\text { Guguak } \\
\text { Sarai } \\
\text { village }\end{array}$ & $\begin{array}{l}\text { Sungai } \\
\text { Durian } \\
\text { village }\end{array}$ & $\begin{array}{c}\text { Taruang- } \\
\text { taruang } \\
\text { village }\end{array}$ \\
\hline $\begin{array}{l}\text { Key informants } \\
\begin{array}{l}\text { General } \\
\text { respondents }\end{array}\end{array}$ & $\begin{array}{l}3 \text { people } \\
\text { 46 people }\end{array}$ & $\begin{array}{l}3 \text { people } \\
18 \text { people }\end{array}$ & $\begin{array}{l}3 \text { people } \\
68 \text { people }\end{array}$ \\
\hline
\end{tabular}

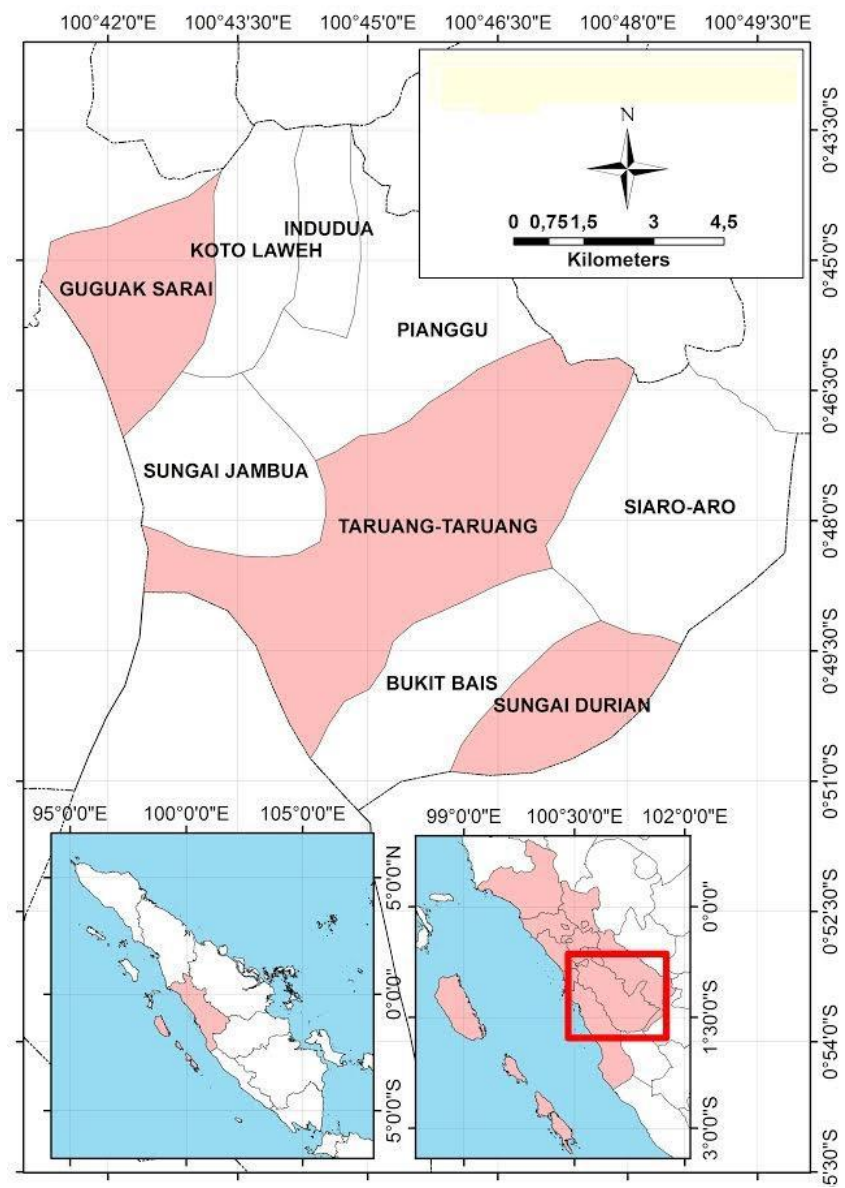

Figure 1. Map of the study area Guguak Sarai, Taruang Taruang and Sungai Durian villages, IX Koto Sungai Lasi Sub-district, Solok District, West Sumatra, Indonesia 


\section{Data analysis}

Data were analyzed using qualitative and quantitative methods. Qualitative analysis used descriptive statistics by grouping plants based on usage category. The cultural significance index (CSI) was calculated using the technique developed by Turner (1988). Assessment of this cultural importance index uses three components namely the quality of use, intensity of use, and the exclusivity of use with the following formula:

$$
\mathrm{CSI}=\sum_{k=1}^{n}(\mathrm{q} \times \mathrm{i} \mathrm{x} e) \mathrm{ni}
$$

CSI is equal to the sum of individual and use values from 1 to $\mathrm{n}$, with $\mathrm{n}$ representing the last use described and the subscript $\mathrm{k}$ representing the value 1 through $\mathrm{n}$, consecutively. For each use given, $q=$ quality value, $i=$ intensity value, and $\mathrm{e}=$ exclusivity value.

\section{RESULTS AND DISCUSSION}

\section{Diversity of the medicinal plants for pregnancy, childbirth, and postpartum}

The Minangkabau ethnic group recognizes pregnancy, childbirth, and postpartum (PCP) as vulnerable stages which may cause maternal death, and they have special treatments and diets to manage the health adversities of these stages. This research found that a total of 42 species, belonging to 39 genera and 25 families, of medicinal plants have been used by the Minangkabau ethnic group to treat PCP related health problems (Table 2). Out of these 43 species, 27 species are represented by 9 families, namely Poaceae (7 species), Arecaceae, Fabaceae, Zingiberaceae (3 species each), Euphorbiaceae, Lamiaceae, Meliaceae, Musaceae, and Asteraceae (2 species each) (Figure 2). The remaining 16 families in this study were represented by single species each.

The number of medicinal plants used by the Minangkabau is less than the number reported for Batak Karo (Silalahi and Nisyawati 2019). Differences in medicinal plants use by local people are influenced by local factors like the environment, topography, ethnicity, and culture (Sujarwo and Cuneva 2015; Silalahi et al. 2015). On the other hand, the popularity of modern medicine, directly or indirectly, influences the degradation of local knowledge pertaining to use of plants as food and medicine (Sujarwo and Cuneva 2015; 2016).

Medicinal plants have been used during PCP to reduce the discomforts associated with pregnancy and to "restore" the body condition after delivery (Theo et al. 2013). Both Batak Karo and Minangkabau ethnics use the same species to treat PCP, such as Cymbopogon citratus, Sauropus androgynus, Cymbopogon nardus, Curcuma longa, Zingiber officinale, and Acorus calamus (Silalahi and Nisyawati 2019).
The results of this study show the decreasing use of medicinal plants by Minangkabau ethnic to treat PCP. The reasons for the local community, especially the younger generation, do not use medicinal plants anymore are: (i) the traditional medicinal practice is associated with mysticism and thus is contrary to religion, (ii) the process of using medicinal plants is more difficult than that of modern medicine, (iii) some medicinal plants are difficult to obtain, and (iv) the easy availability of modern medicinal facilities (midwife).

Pregnancy care by ethnic Minangkabau is intended to strengthen the fetus, reduce nausea, increase appetite, increase fetal weight, prevent bleeding, and facilitate delivery. The roasted extract of the Musa balbisiana roots with Saccharum officinarum L. stem has been used to facilitate delivery, whereas the extract of the Coleus atropurpureus Benth. (leaves) and Cocos nucifera L. (fruits) have been used to prevent bleeding. The extract of Coleus atropurpureus leaves is red, so it is believed to have function similar to blood.

The PCP mothers in the Minangkabau ethnic group believe that they are susceptible to interference by evil spirits, but they are protected by the rhizome Acorus calamus. The volatile oil acorenone concentration in $A$. calamus rhizome which is up to $20.86 \%$ (Venskutonis and Dagilyte 2003) produces a distinctive aroma that provides a relaxing effect. Some ethnic groups in Indonesia utilize plants that contain essential oils, such as Cymbopogon nardus, Cymbopogon citratus, Curcuma longa, and Zingiber officinale, as traditional medicines. Silalahi and Nisyawati (2019) stated that Batak steam-bathing tradition in North Sumatra uses those plants as the main component which provide a relaxing effect. The essential oils in those plants are terpene: $\beta$-pinene, camphor, bornyl acetate, borneol, linalool, D-limonene, fenchone, terpinen-4-ol, and a-terpinene (de Boer et al. 2011). The terpenes also function as antimicrobial and analgesic agents (de Boer et al. 2011).

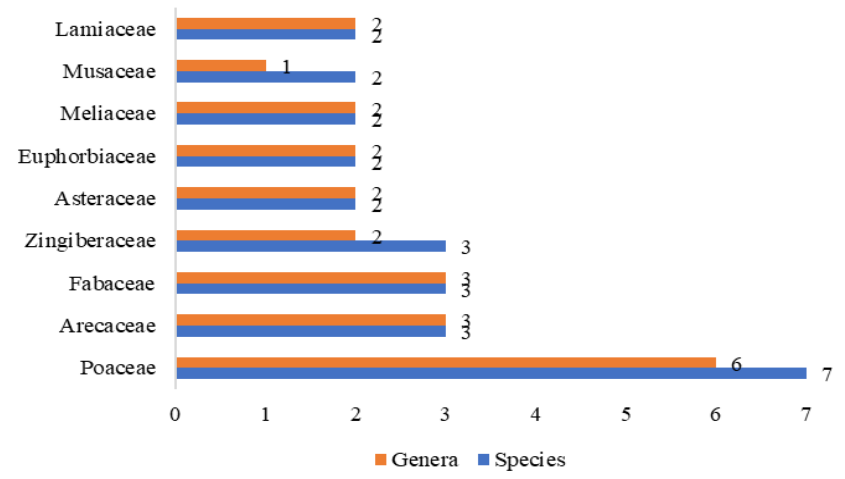

Figure 2. Families with the highest species number of medicinal plants to treat pregnancy, childbirth, and post-partum in the Minangkabau ethnic, West Sumatra, Indonesia 
Table 2. The medicinal plants used to treat pregnancy, childbirth, and postpartum in the Minangkabau Ethnic, West Sumatra, Indonesia

\begin{tabular}{|c|c|c|c|c|c|c|c|c|c|}
\hline Family & Scientific name & Local name & $\begin{array}{c}\text { Cultivated/ } \\
\text { wild }\end{array}$ & $\begin{array}{l}\text { Life } \\
\text { form }\end{array}$ & Part of uses & $\begin{array}{c}\text { CSI } \\
\text { value }\end{array}$ & $\begin{array}{c}\text { Single or } \\
\text { concoction }\end{array}$ & How to use & Uses \\
\hline Acanthaceae & Graptophyllum pictum Griff. & Pudiang hitam & Cultivated & Shrub & Bark & 9 & Single & Fresh, pilis & Headache \\
\hline Amaranthaceae & Amaranthus hybridus L. & Bayam & Cultivated & Herb & Leaves & 25 & Concoctions & Fresh, drink & $\begin{array}{l}\text { Restoring the stamina, increasing breast } \\
\text { milk production }\end{array}$ \\
\hline Araceae & Acorus calamus $\mathrm{L}$. & Jariangau & Wild & Herb & $\begin{array}{l}\text { Rhizomes, } \\
\text { leaves }\end{array}$ & 9 & Concoctions & Boil, drink & Antipyretic \\
\hline \multirow[t]{3}{*}{ Arecaecae } & Areca cathecu Burm.f. & Pinang & Cultivated & Tree & Fruits, roots & 9 & Concoctions & Boil, drink & Antipyretic, healing of woman reproductive \\
\hline & Cocos nucifera $\mathrm{L}$. & Karambia & Cultivated & Tree & Exocarp & 12 & Concoctions & Boil, drink & Cleansing woman reproductive \\
\hline & Arenga pinnata Merr. & Anau & Wild & Tree & Roots & 9 & Concoctions & Boil, drink & Antipyretic, healing of woman reproductive \\
\hline \multirow{2}{*}{ Asteraceae } & Blumea balsamifera DC. & Capo & Wild & Shrub & Leaves & 6 & Single & Boil, drink & Antipyretic \\
\hline & Pluchea indica (L.) Less. & Lontas & Wild & Herb & Leaves & 3 & Concoctions & Fresh, drink & Antipyretic \\
\hline Basellaceae & Anredera cordifolia (Ten.) Steenis & Binahong & Cultivated & Herb & Leaves & 6 & Concoctions & Boil, drink & Antipyretic \\
\hline Caricaceae & Carica papaya $\mathrm{L}$. & Sampelo & Cultivated & Herb & Flowers & 18 & Concoctions & Boil, drink & $\begin{array}{l}\text { Antipyretic, cleansing woman reproductive, } \\
\text { healing of woman reproductive }\end{array}$ \\
\hline Cecropiaceae & $\begin{array}{l}\text { Poikilospermum suavolens } \\
\text { (Blume) Merr. }\end{array}$ & Lundang & Wild & Tree & Roots & 9 & Concoctions & Fresh, drink & Refreshment of body, Restoring the stamina \\
\hline Convolvulaceae & Ipomea batatas Poir. & Ubi jala & Cultivated & Herb & Leaves & 9 & Concoctions & Boil, drink & Healing of woman reproductive \\
\hline Clusiaceae & Garcinia mangostana $\mathrm{L}$. & Manggis & Cultivated & Tree & Stems & 6 & Concoctions & Boil, drink & Cleansing woman reproductive \\
\hline \multirow[t]{2}{*}{ Euphorbiaceae } & Phyllanthus niruri $\mathrm{L}$. & Dukuang anak & Wild & Herb & Aerial part & 6 & Concoctions & Boil, drink & Antipyretic \\
\hline & Sauropus androgynus Merr. & Katu & Cultivated & Shrub & Leaves & 6 & Single & Boil, drink & Cleansing woman reproductive \\
\hline \multirow[t]{3}{*}{ Fabaceae } & Erythrina fusca Lour. & Cangkiang & Wild & Tree & Roots & 6 & Concoctions & Boil, drink & Antipyretic \\
\hline & Parkia speciosa Hassk. & Patai & Cultivated & Tree & Seeds & 9 & Concoctions & Roasted, drink & Restoring the stamina \\
\hline & Tamarindus indica $\mathrm{L}$. & Asam jao & Cultivated & Tree & Fruits & 9 & Concoctions & Boil, drink & Restoring the stamina \\
\hline Gleicheniaceae & $\begin{array}{l}\text { Gleichenia linearis (Burm.) } \\
\text { Clarke. }\end{array}$ & $\begin{array}{l}\text { Pakih ransam, } \\
\text { rasam }\end{array}$ & Wild & Herb & Leaves & 6 & Concoctions & Boil, drink & Cleansing woman reproductive \\
\hline \multirow[t]{2}{*}{ Lamiaceae } & Plectranthus amboinicus Lour. & Bangun bangun & Cultivated & Herb & Leaves & 6 & Concoctions & Boil, drink & Antipyretic \\
\hline & Coleus atropurpureus Benth. & Pudiang merah & Wild & Herb & Leaves & 3 & Concoctions & Fresh & Stop of bleeding \\
\hline Malvaceae & Hibiscus surattensis L. & Asam ruso-ruso & Wild & Shrub & Leaves & 6 & Concoctions & Boil, bathing & Refreshment of body \\
\hline \multirow[t]{2}{*}{ Meliaceae } & Lansium domesticum Jack. & Duku & Cultivated & Tree & Bark & 9 & Concoctions & Boil, drink & Cleansing woman reproductive \\
\hline & Toona sureni Merr. & Kayu surian & Wild & Tree & Bark & 6 & Concoctions & Boil, pilis & Antipyretic and headache \\
\hline Menispermaceae & Cyclea barbata Miers & Kalimpanang & Wild & Herb & Roots & 9 & Concoctions & Boil, drink & Antipyretic and headache \\
\hline \multirow[t]{2}{*}{ Musaceae } & Musa balbisiana Colla. & Pisang batu & Wild & Herb & Roots, stem & 9 & Concoctions & Boil, drink & Cleansing woman reproductive \\
\hline & Musa paradisiaca $\mathrm{L}$. & Pisang buai & Cultivated & Herb & Roots & 9 & Concoctions & Boil, drink & Cleansing woman reproductive \\
\hline Myrtaceae & $\begin{array}{l}\text { Eugenia malaccensis Reinw. ex } \\
\text { Blume }\end{array}$ & Jambak & Cultivated & Tree & Bark & 9 & Concoctions & Boil, bathing & Refreshment of body \\
\hline Piperaceae & Piper betle L. & Siriah & Cultivated & Herb & Leaves & 9 & Concoctions & Boil, drink & Antipyretic \\
\hline
\end{tabular}




\begin{tabular}{|c|c|c|c|c|c|c|c|c|c|}
\hline \multirow[t]{8}{*}{ Poaceae } & Coix lacryma-jobi $\mathrm{L}$. & $\begin{array}{l}\text { Anjalai, Batiah- } \\
\text { batiah }\end{array}$ & Wild & Herb & Seeds & 9 & Concoctions & Boil, drink & Cleansing woman reproductive \\
\hline & Cymbopogon nardus (L.) Rendle. & Sarai harum & Cultivated & Herb & Pseudostem & 9 & Concoctions & Boil, bathing & Refreshment of body \\
\hline & Cymbopogon citratus Stapf & Sarai & Cultivated & Herb & Stem & 9 & Concoctions & Roasted, drink & Restoring the stamina \\
\hline & Imperata cylindrica $(\mathrm{L}$.$) P. Beauv$ & Lalang & Wild & Herb & Rhizomes & 9 & Concoctions & Boil, drink & Cleansing woman reproductive \\
\hline & Oryza sativa $\mathrm{L}$. & Padi & Cultivated & Herb & Seeds & 9 & Concoctions & Fresh, pilis & Refreshment of body \\
\hline & Oryza sativa var. glutinosa & Sipuluik & Cultivated & Herb & Seeds & 9 & Concoctions & Roasted, drink & $\begin{array}{l}\text { Restoring the stamina Increasing breast } \\
\text { milk production }\end{array}$ \\
\hline & Zea mays L. & Jaguang & Cultivated & Herb & Seeds & 9 & Concoctions & Roasted, drink & $\begin{array}{l}\text { Restoring the stamina, Increasing breast } \\
\text { milk production }\end{array}$ \\
\hline & Saccharum officinarum L. & Tabu udang & Cultivated & Herb & Stems & 9 & Concoctions & Boil, drink & Antipyretic \\
\hline Rhizihoraceae & Carallia brachiata (Lourr) Merr. & Maransi & Wild & Tree & Stems & 6 & Concoctions & Boil, drink & Restoring the stamina \\
\hline Rubiaceae & $\begin{array}{l}\text { Uncaria gambir (W. Hunter) } \\
\text { Roxb. }\end{array}$ & Gambia & Cultivated & Shrub & Sap & 9 & Concoctions & Boil, drink & Antipyretic \\
\hline Sapindaceae & Schleichera oleosa (Lour.) Oken. & Kasambi & Wild & Tree & Leaves & 9 & Concoctions & Boil, bath & Refreshment of body \\
\hline \multirow[t]{3}{*}{ Zingiberaceae } & Curcuma longa $\mathrm{L}$. & Kunyik bona & Cultivated & Herb & Rhizomes & 9 & Concoctions & Boil, drink & Antipyretic \\
\hline & Zingiber officinale Rosc. & Sipadeh & Cultivated & Herb & Rhizomes & 6 & Concoctions & Boil, drink & Antipyretic, restoring the stamina \\
\hline & Zingiber purpureum Rosc. & Kunyik bolai & Cultivated & Herb & Rhizomes & 9 & Concoctions & Fresh, drink & Antipyretic \\
\hline
\end{tabular}


The medicinal plants recorded in this study were also reported to be used by other ethnic groups. Such plants include Cymbopogon citratus Stapt, Curcuma longa L, Zingiber officinale Rosc, and Sauropus androgynus Merr. New medicinal plants that are used by mothers of Minangkabau ethnic for PCP include Musa balbisiana Colla and Musa paradisiaca L. (Musaceae), Carallia brachiata (Lour) Merr (Rhizophoraceae), and Lansium domesticum Jack., and Toona sureni Merr. (Meliaceae). The roots and pseudostem of Musa balbisiana and Musa paradisiaca have been used to restore stamina of maternal postpartum, while Lansium domesticum and Toona sureni have been used to cleanse blood during the puerperium. Further research needs to be done to find out bioactive compounds from these plants. Oryza sativa L., Zea mays L. and Ipomea batatas Poir are plants used as sources of carbohydrates, but when they are used in the treatment of $\mathrm{PCP}$, the processing method is different. For example, Zea mays roasted with pseudostems of Cymbopogon citratus and seeds of Parkia speciosa Hassk, brewed with hot water, and used to maintain stamina of pregnant women.

The predominant mode of administration of herbal preparations was drinking (35 species), which was followed by bathing ( 4 species), and applying as a mask paste (3 species). The thirty-five species were used as concoctions, while 7 species were used as single herbs. Fresh extracts are collected from fleshy plant parts, such as Curcuma longa and Zingiber officinale rhizomes and Saccharum officinarum stem. The medicinal plants such as the leaves of Blumea balsamifera, Anredera cordifolia, and Cocos nucifera were prepared by boiling and then the boiled water was used as herbal drink. The respondents are of the opinion that medicinal plants should be processed before consumption for imparting taste, better benefits, easier consumption, and also for ensuring hygiene. Medicinal plants are also boiled and brewed with other additives such as palm sugar (Arenga pinnata), honey, and chicken eggs also to improve flavor and efficacy.

The use of medicinal herbs in the treatment of PCP is believed to be beneficial for antipyretics, cleansing the female reproductive organ, restoring stamina, refreshing the body, healing headaches, increasing breast milk production, and stopping bleeding. The number of species used for each of these purposes is shown in Figure 3. Medicinal plants used for antipyretics are Zingiber purpureum, Curcuma longa, Uncaria gambir, Piper betle, Cyclea barbata, and Toona sureni. The utilization of $T$. sureni as an antipyretic is hitherto not reported and therefore needs further research.

The post-partum maternal bathing method in the Minangkabau ethnic group differs from other ethnic groups such as the Batak ethnicity (Silalahi and Nisyawati 2019). Postpartum mothers in the Minangkabau ethnic group take water that has been mixed with freshly sliced medicinal plants for bathing while the Batak ethnic group take a steam bath. The Batak Karo sub-ethnic used 62 species of medicinal plants, most of which belong to Rutaceae and Zingiberaceae (Silalahi and Nisyawati 2019). The steambathing aims to restore stamina, cleanse the uterus, relaxing, eliminate headaches, reduce cholesterol and hypertension (Silalahi and Nisyawati 2019), while the Minangkabau ethnic bath is to make the body refreshed.

One of the goals of using plants during PCP is to increase breast milk production. The plants used are Sauropus androgynus and Plectranthus amboinicus. Garcinia mangostana, Arenga pinnata, and Gleichenia linearis have been used to clean the female reproductive organs while Hibiscus surattensis, Gleichenia linearis, Eugenia malaccensis, Schleichera oleosa, Cymbopogon nardus, and Curcuma longa have been used for bathing. The initial period of one month is considered unhealthy for postpartum mothers. They are advised to use Phyllanthus niruri, Gleichenia linearis, and Garcinia mangostana to cleanse their reproductive system and uterus.

Ogbe et al. (2009) stated that the purpose of using medicinal plants after childbirth is to treat bleeding, contraception, increasing milk, and treat skin diseases, and that Euphorbia hirta and Ocimum gratissimum were used to increase breast milk by local Africans. Panyaphu et al. (2011) opined that plants used in post-partum also function as antioxidants and antimicrobials. Figure 4 shows the extent of plant parts used as medicinal by Minangkabau ethnic group. Leaves are the predominantly used part (12 species), followed by stems (10 species), roots (6 species), rhizome ( 5 species), and seeds (5 species).

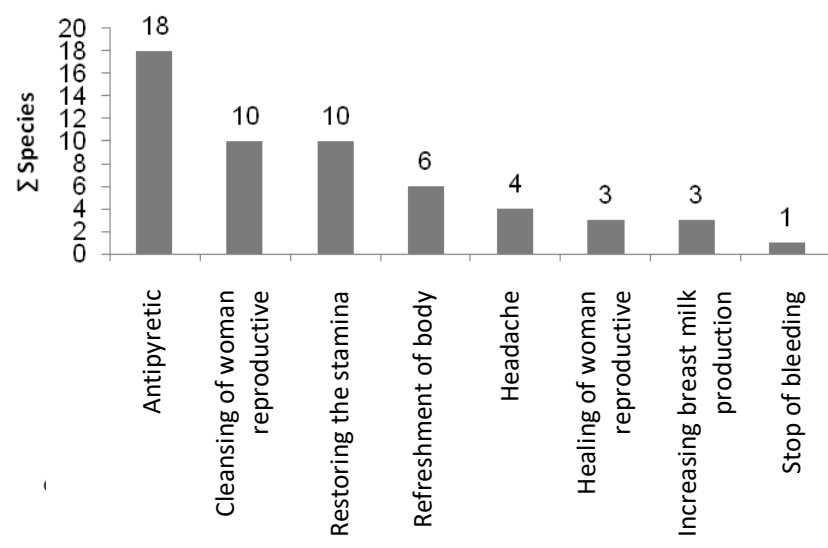

Figure 3. Various benefits of medicinal plants in treatment of PCP and species used by Minangkabau ethnic, in West Sumatra, Indonesia

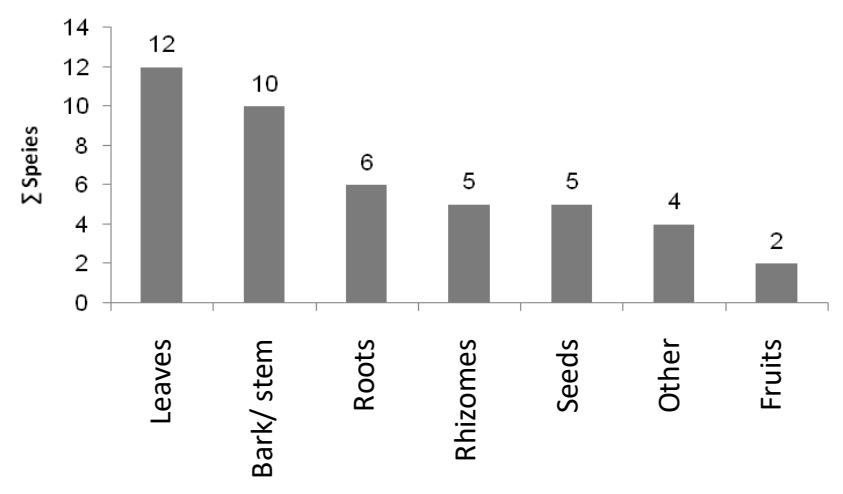

Figure 4. Medicinal plant parts used to treat pregnancy, childbirth and postpartum period by Minangkabau ethnic, in the West Sumatra, Indonesia 


\section{Cultural Significance Index (CSI) of the medicinal plants}

The values of cultural significance index (CSI) of medicinal plants to treat pregnancy, childbirth, and postpartum are classified as very low $(<5)$, low $(6-10)$, moderate (11-15), and high (> 15). Two species, namely Pluchea indica and Coleus atropurpureus have very low CSI values. More than $88 \%$ or 38 species of medicinal plants in this study have low CSI values. Graptophyllum pictum, Areca catechu, Blumea balsamifera, and Anredera cordifolia are some species with low CSI values. Medicinal plants which have low CSI values are rarely used or have few resources, so that people do not recognize and are also underutilized Areca catechu is a plant that is more widely known as an ingredient for betel nut than PCP medicine. The medicinal plants that have a high CSI value are those that are frequently used and easily found in the surrounding environment. They are cultivated, and, therefore, easily recognized and used intensively by the local community. The non-cultivated medicinal plants are rarely used by local people and tend to be forgotten which has implications for the degradation of local knowledge.

\section{Medicinal plant for increased breast milk production}

The problems that are often encountered by postpartum mothers are low milk production, anemia, and being overweight. Adequate milk production is crucial for the growth and development of the baby, therefore post-partum mothers commonly consume vegetables such as bangunbangun (Plectranthus amboinicus) and katuk leaves (Sauropus androgynus). Both of these plants are believed to increase breast milk production.

$P$. ambonicus leaves are cooked much like a vegetable curry by adding spices, such as lemongrass (Cymbopogon citratus), ginger (Zingiber officinale), coriander (Coriandrum sativum), onion (Allium cepa), garlic (Allium sativum), and coconut milk (Cocos nucifera). These vegetables are consumed by breastfeeding mothers, as often as possible. The use of $P$. ambonicus to increase milk production by the $\mathrm{s}$ caused by cultural influence of the Batak ethnic group from North Sumatra. The Batak ethnic is an indigenous ethnic group in North Sumatra that is geographically bordered directly with West Sumatra, resulting in cultural exchange between ethnic cultures. Batak people, especially the Simalungun Batak, use $P$. ambonicus as the main menu for breastfeeding mothers. To improve the taste, additives like chicken meat and spices are employed. Besides, increasing breast milk, consumption of $P$. ambonicus also increases stamina (Hasibuan 2014). Plectranthus amboinicus is generally cultivated in home gardens, so that it is easily accessible to the local community. It is harvested by cutting branches and young shoots, after that new shoots will appear from branches that have been cut.

Arumugam et al. (2016) stated that the nutrients in the $P$. ambonicus are protein $(0.6 \%)$, Calcium $(0.158 \%)$, Potassium $(0.138 \%)$ and Ferrum $(0.262 \%)$. The Ferrum in $P$. ambonicus increases blood and prevents anemia in postpartum mothers. It also contains various secondary metabolites such as tannins, saponins, flavonoids, steroid glycosides and polyuronides (Asiimwe et al. 2014;
Sathasivam and Elangovan 2011); alkaloids, cardiac glycosides, terpenoids, and flavonoids (Sathasivam and Elangovan 2011). The major phenolic compounds in $P$. ambonicus are rosmarinic acid $(6.160 \mathrm{mg} / \mathrm{g})$, followed by caffeic acid $(0.770 \mathrm{mg} / \mathrm{g})$, routine $(0.324 \mathrm{mg} / \mathrm{g})$, gallic acid $(0.260 \mathrm{mg} / \mathrm{g})$, quercetin $(0.15 \mathrm{mg} / \mathrm{g})$, and $\mathrm{p}$-coumaric acid $(0.104 \mathrm{~m} / \mathrm{g})$ (Bhatt et al. 2013). The terpenoid essential oils contained in leaves and stems of $P$. ambonicus results in providing a distinctive aroma. The main essential oil found in $P$. ambonicus leaves were linalool (50,3\%), neryl acetate $(11,6 \%)$, geranyl acetate $(11,7 \%)$, and carvacrol $(14,3 \%)$ (Asiimwe et al. 2014). The other compositions of $P$. Amboinicusis were $\beta$-Myrcene, 4 -Carene, $\gamma$-terpinene, $\beta$ ocimene, $\beta$-cymene, linalool, $\alpha$-caryophyllene, neryl acetate, geranyl acetate, and nerol carvacrol (Asiimwe et al. 2014). P. ambonicus, owing to its rich nutrients and phytochemicals, can be potentially developed as food and nutraceutical source (Bhatt et al. 2013).

Plectranthus amboinicus has been reported as antibacterial (Wadikar and Patki 2016; El-hawary et al. 2013) and also has antifungal activities (Wadikar and Patki 2016; Manjamalai et al. 2012). The essential oil of $P$. amboinicus leaves inhibited growth of Klebsiella pneumoniae (Goncalves et al. 2012), Staphylococcus aureus (Manjamalai et al. 2012; Bhatt et al. 2013; Astuti et al. 2012), Bacillus cereus, Escherichia coli, Yersinia enterocolitica (Bhatt et al. 2013), Bacillus subtilis (Astuti et al. 2012; Bhatt and Negi 2012), Klebsiella planticola (Vanaja and Annadurai 2013), Pseudomonas aeruginosa (Astuti et al. 2012; Manjamalai et al. 2012), and Salmonella thypi (Astuti et al. 2012).

Sauropus androgynus has been long used as a vegetable to increase breast milk production by Minangkabau ethnic and is more familiar than P. ambonicus. S. androgynous is cultivated in home garden and easily found in the surrounding environment. The Minangkabau people have been long consuming $S$. androgynus, and they have not reported any poisoning due to its consumption. In Taiwan and Japan, it is used as a slimming and anti-obesity agent (Bunawan et al. 2011). In Taiwan (1995) and China (2005), the consumption of $S$. androgynus has been reported to cause lung dysfunction called bronchiolitis obliterans (Bunawan et al. 2011: Lai et al. 1996; Yu et al. 2006). Bronchiolitis obliterans is characterized by inflammation of the airways, broccoli fibrotic lesions, and narrowing of the lumen (Cottin and Cordier 2013). Xin et al. (2006) reported that giving juice of $S$. androgynus leaves to cells at certain doses resulted in obliteration of the lysosome and Golgi apparatus but did not result in chromosomal changes. The method of $S$. androgynus processing in Minangkabau ethnic is different from Taiwan and China. In Taiwan, $S$. androgynus leaves and young shoots are used as fresh material (Lai et al. 1996; Yu et al. 2006; Bunawan et al. 2011), while the Minangkabau people use after boiling them. Papaverine is an alkaloid which results in bronchiolitis obliterans (Bunawan et al. 2011), and this compound is degraded in the presence of heating (Lai et al. 1996). Thus, boiling of $S$. androgynus by Minangkabau ethnic makes it a relatively safe diet. 
The use of $S$. androgynus in postpartum mothers, in addition to increasing breast milk production, is thought to reduce weight and also increase the number of red blood cells. Yu et al. (2006) stated that S. androgynus leaves contain a chemical compound called is 3-O- $\beta$-D-glucosyl$(1 \rightarrow 6)-\beta$-D-glucosyl-kaempferol that has anti-obesity properties. Hasimun et al. (2018) reported that $S$. androgynous leaf extract at doses of 50, 100, and 200 $\mathrm{mg} / \mathrm{kg}$ could increase the number of red blood cells and reduce the rate of stretching. S. androgynus leaf extract at a dosage of $200 \mathrm{mg} / \mathrm{kg}$ has anti-anemic and analgesic effects, simultaneously.

\section{ACKNOWLEDGEMENTS}

The authors wish to express their gratitude to the Minangkabau ethnic people in the Guguak Sarai, Taruang Taruang, and Sungai Durian villages of West Sumatra, Indonesia for allowing us to undertake this research in their premises. The support provided by Drug Plant Research Institute Solok, Plant Taxonomy Laboratory of Universitas Indonesia, Depok and Herbarium Bogoriense, Cibinong, Bogor during botanical identification of the medicinal plants is also gratefully acknowledged.

\section{REFERENCES}

Abdillahi HS, Van Staden J. 2013. Application of medicinal plants in maternal healthcare and infertility: a South African perspective. Planta Med 79: 591-599.

Arumugam G, Swamy MK, Sinniah UR. 2016. Plectranthus amboinicus (Lour.) Spreng: botanical, phytochemical, pharmacological and nutritional significance. Molecules 21 (4): $369 . \quad$ DOI: 10.3390/molecules21040369.

Asiimwe S, Borg-Karlsson AK, Azeem M, Mugisha KM, Namutebi A, Gakunga NJ. 2014. Chemical composition and toxicological evaluation of the aqueous leaf extracts of Plectranthus amboinicus Lour. Spreng. Int J Pharm Sci Invention 3 (2): 19-27.

Astuti P, Sudarsono S, Nisak K, Nugroho GW. 2014. Endophytic fungi isolated from Coleus amboinicus Lour exhibited antimicrobial activity. Adv Pharm Bull 4 (Suppl 2): 599-605

Bhatt P, Joseph GS, Negi PS, Varadara MC. 2013. Chemical composition and nutraceutical potential of Indian borage (Plectranthus amboinicus) stem extract. J Chem. 2013: 320329. DOI: $10.1155 / 2013 / 320329$.

Bhatt P, Negi PS. 2012. Antioxidant and antibacterial activities in the leaf extracts of Indian borage (Plectranthus amboinicus). Food Nutr Sci 3: 146-152.

Bunawan H, Bunawan SN, Noor NM. 2015. Sauropus androgynus (L.) Merr. induced bronchiolitis obliterans: from botanical studies to toxicology. Evid-Based Compl Altern Med. 2015: 714158. DOI: $10.1155 / 2015 / 714158$

de Boer HG, Lamxay V, Björk L. 2011. Steam sauna and mother roasting in Lao PDR: practices and chemical constituents of essential oils of plant species used in postpartum recovery. BMC Compl Altern Med 11: 128. DOI: $10.1186 / 1472-6882-11-128$

de Boer H, Lamxay V. 2009. Plants used during pregnancy, childbirth and postpartum healthcare in Lao PDR: a comparative study of the Brou, Saek and Kry ethnic groups. J Ethnobiol Ethnomed 5: 25. DOI:10.1186/1746-4269-5-25.

De Padua LS, Bunyapraphatsara, Lemmens RHMJ. 1999. Plant Resources of South-East Asia No 12 (1). Backhyus Publishers, Leiden.

El-Hawary SS, El-Sofany RH, Abdel-Monem AR, Ashour RS, Sleem AA. 2013. Seasonal variation in the composition of Plectranthus amboinicus (Lour.) Spreng essential oil and its biological activities. Am J Essential Oils Nat Prod 1 (2): 11-18.

Emmanuel MM, Didier DS. 2012. Traditional knowledge on medicinal plants used by ethnic communities in Douala, Cameroon. Eur J Med Plants 2 (2): 159-176.

Goncalves TB, Braga MA, de Oliveira FFM, Santiago GGMP, Carvalho CBM, Cabral PB, Santiago TDM, Sousa JS, Barros EB, do Nascimento RF, Nagao-Dias AT. 2012. Effect of subinhibitory and inhibitory concentrations of Plectranthus amboinicus (Lour.) Spreng essential oil on Klebsiella pneumoniae. Phytomedicine 19: 962- 968.

Hasibuan APAZ. 2014. Hacytotoxic effect of n-hexane, ethyl acetate and ethanol extracts of Plectranthus amboinicus, (Lour.) Spreng.) on HeLa and Vero cells lines. Intl J Pharm Tech Res 6 (6): 1806-1809.

Hasimun P, Aligita W, Nopitasari I. 2018. Anti-anemic and analgesic activity of Sauropus androgynous L. Merr on female mice model. Int J Pharm Phytopharmacol Res 8 (1): 98-102.

Hoang VS, Bas P, Kebler PAJ. 2008. Traditional medicine plant in Ben En National Park, Vietnam. Blumea 53: 569-601.

Jain A, Katewa SS, Chaudhary BL, Galav P. 2004. Folk herbal medicines used in birth control and sexual diseases by tribals of southern Rajasthan, India. J Ethnopharmacol 90: 171-177.

Khairiah A. 2017. Etnomedisin dan Nilai Ekonomi Tumbuhan Obat Pada Etnis Minangkabau di Kecamatan IX Koto Sungai Lasi, Solok, Sumatra Barat. Tesis. Departement Biologi, FMIPA, Universitas Indonesia, Depok. Indonesia. [Indonesian]

Lai RS, Chiang AA, Wu MT, Wang JS, Lai NS, Lu JY, Ger LP. 1996. Outbreak of bronchiolitis obliterans associated with consumption of Sauropus androgynus in Taiwan. Lancet 348: 83-85.

Lundh, ECS. 2007. Plant use in ante and postpartum health care in Lao PDR. [Dissertation]. Department of Systematic Botany, Uppsala University, Sweden.

Manjamalai A, Alexander T, Grace VMB. 2012. Bioactive evaluation of the essential oil of plectranthus amboinicus by GC-MS analysis and its role as a drug for microbial infections and inflammation. Int $\mathbf{J}$ Pharm Pharm Sci 4 (3): 205-211.

Martin GJ. 1995. Ethnobotany A People and Plants Conservation Manual. Chapman and Hall, London, UK.

Nain N, Goyal S, Ramawat KG. 2011. Ramawat evaluation of antioxidant properties and total phenolic content of medicinal plants used in diet therapy during postpartum healthcare in Rajasthan. Intl J Pharm Pharm Sci 3 (1): 248-253.

Ogbe FMD, EruogunOL, Uwagboe M. 2009. Plants used for female reproductive health care in Oredo local government area, Nigeria. Sci Res Essay 4 (3): 120-130.

Panyaphu K, Sirisa-Ard P, Ubol PN, Nathakarnkitku S, Chansakaow S, On TV. 2012. Phytochemical, antioxidant, and antibacterial activities of medicinal plants used in Northern Thailand as postpartum herbal bath recipes by the Mien (Yao) community. Phytopharmacology 2 (1): $92-105$

Silalahi M, Nisyawati, Walujo EB, Supriatna J. 2015. Local knowledge of medicinal plants in sub-ethnic Batak Simalungun of North Sumatra, Indonesia. Biodiversitas 16 (1): 44-54.

Silalahi M. Nisyawati. 2019. An ethnobotanical study of traditional steambathing by the Batak people of North Sumatra, Indonesia. Pac Conserv Biol 25 (3): 266-282

Sujarwo W, Caneva G. 2016. Using quantitative indices to evaluate the cultural importance of food and nutraceutical plants: Comparative data from the Island of Bali (Indonesia). J Cult Heritage 18: 342-348.

Sujarwo W. Caneva G. 2015. Ethnobotanical study of cultivated plants in home gardens of traditional villages in Bali (Indonesia). Hum Ecol. DOI: $10.1007 / \mathrm{s} 10745-015-9775-8: 1-10$

Suryadarma IGP. 2010Diversity of plants of fitness material in the Rukmini Tatwa manuscripts of Bali Community. Biota 15 (2): 294305.

Takahashi Y, TamakoshiK, Nagoya. 2014. Factors associated with early postpartum maternity blues and depression tendency among Japanese mothers with full-term healthy infants. J Med Sci 76: 129-138.

Teoh CS, Aizul MHI, Suriyani WMWF, Ang SH, Huda MZN, Nor Azlin MI, Rohana J. 2013. Herbal ingestion during pregnancy and postpartum period is a cause for concern. Med J Malays 68 (2): $157-$ 160.

Tsu VD, Langer A, Aldrich T. 2004. Postpartum hemorrhage in developing countries: is the public health community using the right tools? Intl J Gynecol Obstetrics 85 (Suppl. 1): S42-S51. 
Turner NJ. 1988. "The importance of a rose": evaluating the cultural significance of plants in Thompson and Lillooet Interior Salish. Amer Anthropol New Ser 90 (2): 272-290.

Vanaja M, Annadurai G. 2013. Coleus aromaticus leaf extract mediated synthesis of silver nanoparticles and its bactericidal activity. Appl Nanosci 3: 217-223.

Venskutonis PR, Dagilyte A. 2005. Composition of essential oil of sweet flag (Acorus calamus L.) leaves at different growing phases. J Essential Oil Res 15 (5): 313-318
Wadikar DD, Patki FE. 2016. Coleus aromaticus: a therapeutic herb with multiple potentials. J Food Sci Technol 53 (7): 2895-2901.

Wakhidah AZ, Silalahi M, Pradana DH. 2017. Inventory and conservation plant of oke sou traditional ceremony; A welcoming tradition of maturity girl on the community of Lako Akediri Village, West Halmahera, Indonesia. Biodiversitas 18 (1): 65-72.

www. The Plantlist. 2017. The Plantlist Database. www.theplantlist.org.

Yu SF, Chen TM, Chen YH. 2007. Apoptosis and necrosis are involved in the toxicity of Sauropus androgynous in an in vitro study. Formosa Med Assoc 106 (7): 537-547. 